\title{
Useful plants and their relation to archaeological sites in the Serra de Carajás, Brazil
}

\author{
RONIZE S. SANTOS ${ }^{1}$, MÁRLIA COELHO-FERREIRA ${ }^{1}$, PEDRO G.C. LIMA ${ }^{2}$ and MARCOS P. MAGALHÃES ${ }^{1}$ \\ ${ }^{1}$ Museu Paraense Emílio Goeldi, Coordenação de Botânica, Av. Perimetral, 1901, Terra Firme, 66077-830 Belém, PA, Brazil \\ ${ }^{2}$ Programa de Pós-Graduação em Ciências Florestais, Universidade Federal Rural de Pernambuco, Av. \\ Dom Manoel de Medeiros, s/n, Campus Dois Irmãos, Dois Irmãos, 52171-900 Recife, PE, Brazil
}

Manuscript received on November 10, 2017; accepted for publication on July 9, 2018

\begin{abstract}
How to cite: SANTOS RS, COELHO-FERREIRA M, LIMA PGC AND MAGALHÃES MP. 2019. Useful plants and their relation to archaeological sites in the Serra de Carajás, Brazil. An Acad Bras Cienc 91:e20170909. DOI 10.1590/0001-3765201920170909.
\end{abstract}

\begin{abstract}
Multidisciplinary studies including archeology and ethnobotany that seek to understand human interventions on the landscape have obtained important results concerning Amazon biodiversity. This study aims to identify the useful plants in different phytophysiognomies related to archeological sites in the Serra de Carajás, in the state of Pará, as well as expand knowledge of the local flora. Information was collected in 76 parcels located in the influence areas of 15 archaeological sites: 45 in forest vegetation, 30 in canga vegetation and 1 in palm swamps. The species were categorized as either medicinal, food, game attractants, firewood, toxic, ritualistic and material. An assessment of the plants use potential by family was done using regression analysis for the taxa inventoried. All the phytophysiognomies studied in the vicinity of archaeological sites were expressive regarding useful species. The most representative categories were medicinal, material, game attractant, firewood and food. The floristic features related to the use of plant species by family were also expressive for Fabaceae, Myrtaceae and Chrysobalanaceae. The phytophysiognomies identified near archaeological sites feature several plant resources in different use categories, highlighting the value of local ecosystems and their potential for human use.
\end{abstract}

Key words: Archeology, use category, ethnobotany, phytophysiognomy.

\section{INTRODUCTION}

Human interaction with the Amazon environment over time has resulted in an immense genetic heritage of useful plants, the greater part awaiting study by the scientific community. Modern indigenous communities, for instance, borrowing on locally available resources, change the vegetation and environment they manage (Alcorn 1981, Anderson and Posey 1985, Balée 1994). Such interference

Correspondence to: Ronize da Silva Santos

E-mail: ronizess@yahoo.com.br

ORCid: https://orcid.org/0000-0002-8387-8614 has contributed to the diversity of plants in several instances and, depending on its intensity, can cause changes in local species composition and in landscape features (Alcorn 1981, Anderson and Posey 1985).

Multidisciplinary studies in the human and natural sciences aimed at understanding the human interaction with the environment have obtained important findings concerning how Amazonian cultures have helped shape modern biodiversity within several phytophysiognomies (Heckenberger et al. 2003, Levis et al. 2012, Balée et al. 2014, Scheel-Ybert et al. 2016). Botanical 
inventories near archaeological sites are a strategy for investigating the evidence of anthropogenic interventions in the landscape (Erickson and Balée 2006, Levis et al. 2012, Balée et al. 2014) and can be useful for analyzing the context of different dwelling contexts, for instance, helping to identify whether a site was used for cultivation, habitation, ritual, or other. Plants have versatile uses by humans, and make up both tangible and intangible heritage. This has been shown by several studies that catalogued useful Amazon plants and verified their versatility for uses such as medicine, food, toxic, ritual, firewood and fiber provider (Le Cointe 1947, Grenand et al. 1987, Schultes and Raffauf 1990, Balée 1994, Berg 2010, Cavalcante 2010).

The Carajás region has many archaeological sites, both in lowland areas, where open sites prevail, and in plateaus, where there are mostly cave and rock shelters sites (Magalhães et al. 2016). The archaeological context in this region is important for apprehending the processes of human occupation and the use of natural resources in Amazonia (Kipnis et al. 2005, Bueno and Pereira 2015, Falci and Rodet 2016, Magalhães et al. 2016).

This article aims at identifying the useful plants present in different phytophysiognomies related to archaeological sites in the Serra de Carajás region, (Pará State), as well as to expand current knowledge of the local flora. The questions addressed were: 1) what is the floristic composition in those phytophysiognomies? 2) In which use category do the inventoried species belong? 3) Is there any floristic pattern regarding those useful plants potential considering botanical family?

\section{MATERIALS AND METHODS}

\section{STUDY AREA DESCRIPTION}

The study area is in Carajás National Forest, which is located within the Serra de Carajás Mineral Province, in southeastern Pará, Brazilian Amazon. The region's geomorphology comprises a group of plateaus that reach $800 \mathrm{~m}$ elevation, with dramatic relief that stands out from local topography (IBAMA 2003). The study was done around archaeological sites, located on plateaus N1 and $\mathrm{N} 3$ in the Northern Range (Serra Norte) (6 ${ }^{\circ}{ }^{\prime} 8^{\prime \prime} \mathrm{S}$ and $50^{\circ} 17^{\prime} 47^{\prime \prime} \mathrm{W}$ ) and S11D in the southern range (Serra Sul) (6 $6^{\circ} 24^{\prime} 48^{\prime \prime S}$ and $\left.50^{\circ} 19^{\prime} 6^{\prime \prime} \mathrm{W}\right)$, located in the municipalities of Parauapebas and Canaã dos Carajás, respectively (Figure 1).

Serra de Carajás presents a complex of diverse caves and rock shelters with archaeological remains that have been dated at more than 11,000 years BP, comprising the end of the Pleistocene and all of the Holocene. The difficult access to these areas in recent times has contributed to their preservation. The beginning of this occupation is related to pre-ceramist populations and, more recently, occupations of ceramist groups who made use of the tropical forest and savanna resources typical of the region (Magalhães 2005, Magalhães et al. 2016).

The climate is classified within the Köppen system as type "AW", which comprises a strong dry season. The relative humidity is higher than $80 \%$ during the whole year (IBAMA 2003). In the plateau areas, there are acid soils with low nutritional content, so that organic matter content and soil depth highly influences the local phytophysiognomy (Nunes et al. 2015).

The flora of Carajás may be generally separated into forest and non-forest. The forest is ombrophilous, containing several types including open forest with a higher light index, forest rich in vines and palms and closed canopy forests with very dense biomass (Secco and Mesquita 1983). In the Serra de Carajás, forests are distributed in high and lowlands (montane and submontane) (IBAMA 2003). Montane areas comprise all areas within this typology that are over $500 \mathrm{~m}$ elevation, and submontane are lower than 500 m elevation (Brasil 1974).

On top of plateaus, however, the montane forest is different. In some parts of the plateaus, there are isolated forest remnants, which are higher and 


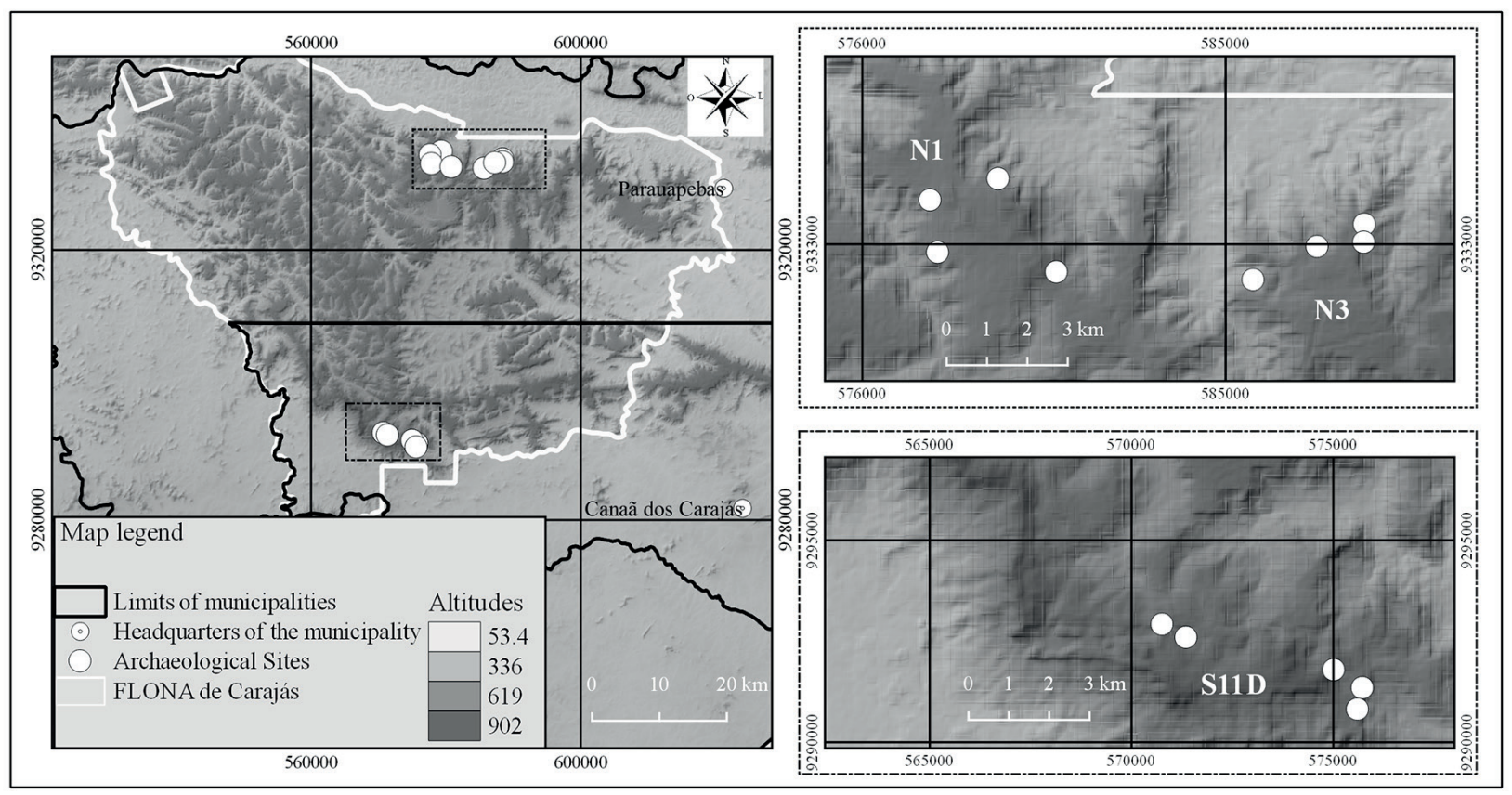

Figure 1 - Location map of the sites inventoried in plateaus N1 and N3 (Serra Norte) and S11D (Serra Sul), Carajás National Forest (FLONA de Carajás), Pará, Brazilian Amazon. By Carlos Barbosa, 2018.

denser in relation to the surrounding scrub savanna or canga. These areas, locally called "capão forest" may occur around lagoons, in small valleys, along steep valleys and canyons, linked or not to caves, both in the center and along the borders of plateaus (Nunes 2009, Schaefer et al. 2012). In other places, the montane forest comprises a more continuous strip of forest along the plateau borders, in some times, an ecotone area between the canga vegetation and the forested slopes. Its structure resembles the inner plateau capão forests; however, it is connected to the surrounding forests (Nunes 2009, Nunes et al. 2015). Both this vegetation and capão forests have plant communities that resemble those found in secondary vegetation (Morellato and Rosa 1991).

The forested slopes also have ombrophilous features and occur along the steeper slopes in the montane areas (Paradella et al. 1994, Morellato and Rosa 1991). This vegetation probably had expansions and retractions during Amazonia's periods of climatic change (Hermanowski et al. 2012).

Palm swamps comprise another forest phytophysiognomy not so commonly found on the plateaus and they feature isolated forest remnants located in the middle of the canga vegetation, inside a valley where rainwater and sediments are deposited. Since part of this area stays wet throughout the year, even during drought seasons, the vegetation is marked by the presence of buriti (Mauritia flexuosa) and buritirana (Mauritiella armata), associated with forest and shrub communities (Morellato and Rosa 1991).

The non-forest vegetation is located on the top of the plateau areas and grows over a soil of "canga", where grasses and shrubs prevail and trees are rare (Morellato and Rosa 1991). This environment remarkably testifies to the environmental changes that occurred in the Amazon during the transition from the Pleistocene to the Holocene in the end of the last glaciation (Absy et al. 1991, Hermanowski et al. 2012).

\section{DATA COLLECTION AND ANALYSIS}

The floristic inventories were done from June 2013 to July 2014. Seventy-six parcels were set within the influence area of 15 archaeological sites and 
distributed along Serra Norte and Serra Sul: 45 in forest areas, 30 in canga vegetation and 1 in palm swamp. The parcels sizes and measuring criteria are listed in Table I.

Botanical samples were collected and identified in the field by a parataxonomist. Sample identification was then revised at Emílio Goeldi Museum's MG herbarium and submitted to analysis from experts for confirmation and inclusion into the collection. The ones that did not enter this collection are kept in the collection of the museum's ethnobotany laboratory. The classification system adopted was Angiosperm Phylogeny Group III (APG III 2009), and the species scientific names were confirmed and updated according to the Lista de Espécies da Flora do Brasil (2015) database, Missouri Botanical Garden (2015) or The Plant List (2015), respectively, and in complimentary ways.

All information related to the use of the species was gathered by consulting specialized literature $(\mathrm{N}=44)$ involving traditional populations from Amazonia, except for some species from canga vegetation, which required consulting studies done in other biomes. The species classification within the use categories was based on Balée (1986, 1994); however, "toxic" and "material" were adopted from Cook (1995) (Table II).

The assessment of use potential by botanical families was done according to Moerman (1996), with support of program Past 3.0. According to the author, the selectivity measure corresponds to the residual value resulting from the regression analysis, in other words, the difference between the amount of useful species predicted by the analysis for each family and the real amount of useful species recorded. In this study, the independent variable was the amount of species inventoried, whereas the dependent variable was the amount of species cataloged.

\section{RESULTS AND DISCUSSION}

\section{RICHNESS AND FLORISTIC COMPOSITION}

The inventory comprised 2,671 individuals from 275 species, distributed within 178 genus and 75 families. Eight specimens were identified to the genus level. Serra Norte presented a richness of 217 species, with 173 comprising forest vegetation and 67 from canga. Serra Sul comprised 156 species, 115 of which are from forest vegetation, 49 from canga and 25 from palm swamps. Even though this study considered the archaeological sites as sampling criterion, the richness and floristic composition do not differ from earlier studies done in Carajás. The result of Silva et al. (1996) comprised 232 inventoried species in several plateaus in Serra Norte. Regarding canga vegetation, Nunes (2009) identified 57 exclusive species from this environment, in Serra Sul. Regarding palm swamps, 15 species were inventoried by Morellato and Rosa (1991) in Serra Norte.

Forest vegetation consists of 60 families, among which Annonaceae (10 sp), Sapindaceae (9) and Chrysobalanaceae (8) were found only in this phytophysiognomy and are among the most representative in number of species. From the 40 families found in canga vegetation, some of them, such as Cactaceae, Marcgraviaceae, Velloziaceae and Verbenaceae, had only one species each and are exclusive to this kind of vegetation.

In palm swamps, 18 families were also found in the other phytophysiognomies, with emphasis on Melastomataceae and Arecaceae, the latter also found in forest vegetation. In Serra Norte, individuals of the family Arecaceae found in palm swamps are comprised exclusively of Mauritiella armata (Morellato and Rosa 1991). In the present study, M. armata was also registered; however, Mauritia flexuosa was the most frequent. Fabaceae (34), Melastomataceae (18), Rubiaceae (16) and Lauraceae (10) were the most expressive families 
TABLE I

Sampling criteria by phytophysiognomy in Northern Range (Serra Norte) and Southern Range (Serra Sul).

\begin{tabular}{cll}
\hline Parcels & \multicolumn{1}{c}{ Forest vegetation and Palm Swamps } & \multicolumn{1}{c}{ Canga vegetation } \\
\hline $20 \mathrm{~m} \times 5 \mathrm{~m}$ & All individuals with diameter at breast height $(\mathrm{DBH}) \geq 5 \mathrm{~cm}$ & $\begin{array}{l}\text { All individuals with diameter at ground level } \\
(\mathrm{DGH}) \geq 5 \mathrm{~cm}\end{array}$ \\
$5 \mathrm{~m} \times 2 \mathrm{~m}$ & $\begin{array}{l}\text { All individuals with diameter at breast height }(\mathrm{DBH}) \text { below } 5 \\
\mathrm{~cm} \text { and above } 1 \mathrm{~cm}\end{array}$ & $\begin{array}{l}\text { All individuals with diameter at ground level } \\
(\mathrm{DGH}) \text { below } 5 \mathrm{~cm} \text { and above } 1 \mathrm{~cm}\end{array}$ \\
$\begin{array}{l}\text { All herbaceous individuals or sprouts with diameter at ground } \\
\text { level }(\mathrm{DGH})<1 \mathrm{~cm}\end{array}$ & All herbaceous individuals or DGH $<1 \mathrm{~cm}$ \\
\hline
\end{tabular}

TABLE II

Use categories adopted for the classification of species inventoried in archaeological sites in Carajás.

\begin{tabular}{ll}
\hline \multicolumn{1}{c}{ Use category } & \multicolumn{1}{c}{ Description } \\
\hline Medicinal & Plants used to treat human diseases. \\
Food & Plants used on human feeding. \\
$\begin{array}{l}\text { Food/Game } \\
\text { attractant }\end{array}$ & Plants consumed by animals, working as attractants for preys (birds and land animals). \\
Firewood & $\begin{array}{l}\text { Plants used as firewood and for lighting, including species that have resins or inflammable and aromatic } \\
\text { latex, used to light and perfume houses at night. }\end{array}$ \\
Toxic & $\begin{array}{l}\text { Poisonous plants for animals, used for fishing and hunting; insecticides (repellents), according to indigenous } \\
\text { perception. }\end{array}$ \\
Ritualistic & $\begin{array}{l}\text { Plants considered as magical or used in ceremonies by indigenous people. This category includes } \\
\text { hallucinogen and narcotic plants. }\end{array}$ \\
Material & $\begin{array}{l}\text { Plants used for building houses, canoes, handicrafts, musical instruments, weapons, domestic tools, etc. } \\
\text { This category includes wood, straw, fibers, exudates (oil-resins, resins, latex), and oils extracted from fruits. }\end{array}$
\end{tabular}

in number of species occurring over all of the vegetation features analyzed.

\section{SPECIES DISTRIBUTION BY USE CATEGORY}

Among the 275 species inventoried, 184 have uses recorded in the literature. They comprise seven use categories: medicinal, food, game attractant, firewood, toxic, ritual and material (see Supplementary Material - Table SI). The categories with highest richness were medicinal (122 sp), material (90), game attractant (78), firewood (64) and food (58). The number of useful species between Serra Norte and Serra Sul were different; however, they had 74 species in common. There were small variations in the category ranking between the phytophysiognomies, so that the medicinal category had the most remarkable variation. The representativeness of the category "game attractant" stands out, in part due to the effort of some authors to cover this category in their studies, which include a remarkable number of species, mainly in indigenous communities (Figure 2).

Medicinal - More expressive in terms of number of species (Table SI), in this category the uses are related to treating several diseases and symptoms, such as stomach diseases, diarrheas, rheumatic and bone pain, and dermatosis, besides being used in the healing of wounds. Others include stimulant, aphrodisiac, and contraceptive properties, for instance, Abuta grandifolia, one of the most used species by indigenous communities for such purposes (Balée 1994). Such that, Caraipa 


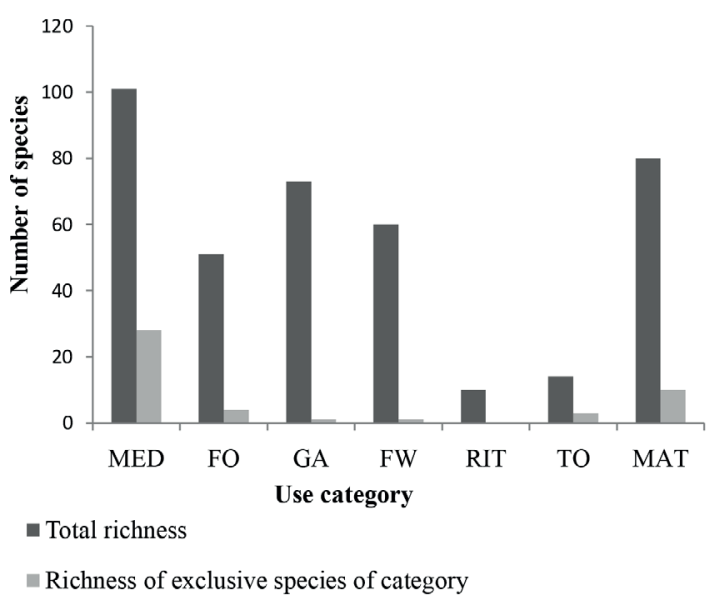

a)

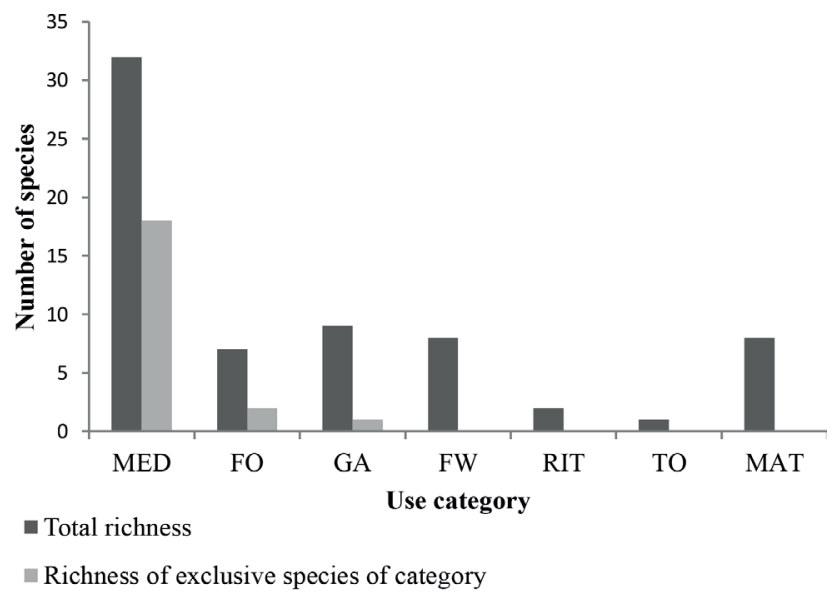

b)

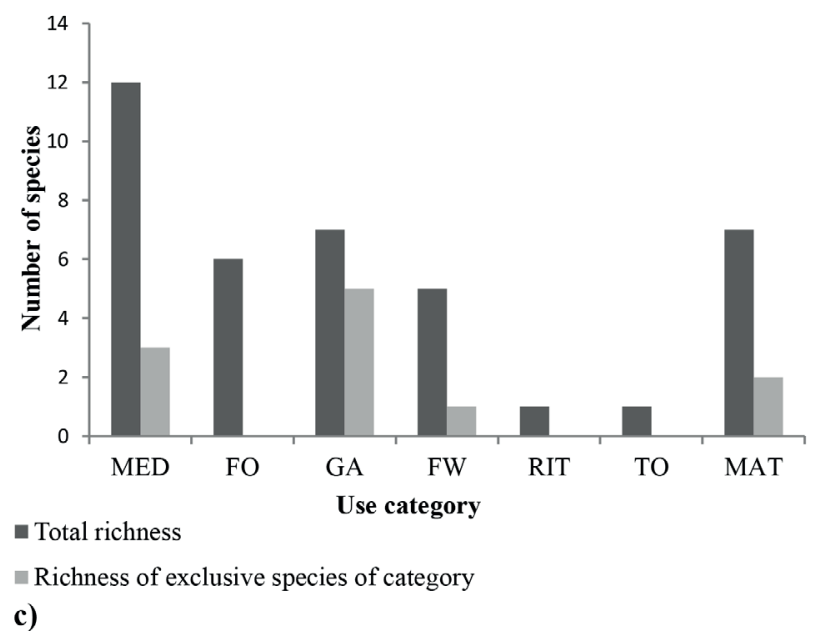

Figure 2 - Categories use of plants in differents phytophysiognomies in Serra de Carajás. a) Forest vegetation; b) Canga vegetation; c) Palm Swamp.

densifolia, Cedrelinga cateniformis, Dialium guianense, Dipteryx odorata, Duroia hirsuta, Handroanthus serratifolius, Hirtella racemosa and Quiina pteridophylla are also reported as species found exclusively in forest vegetation.

Among the species found only in canga vegetation, there were Smilax cf. campestris, Cassytha filiformis, Sauvagesia cf. erecta, Lippia aff. origanoides' and Cochlospermum orinocense; this last one is indicated for bruises and is a very well-known febrifuge (Le Cointe 1947, Egg 1993). In palm swamps, Caraipa grandifolia, Virola surinamenses and Heisteria acuminata are recommended for wounds and skin infections, since they have healing properties (Le Cointe 1947, Revilla 2002, Berg 2010). Simarouba amara, used for malaria, fevers, dysentery, with well-known tonic hemostatic properties (Le Cointe 1947, Amorozo and Gély 1988) is the only species found in all three environments studied.

Some of the plants found had exclusively medicinal uses, such as Connarus perrottetii and Ouratea castaneifolia, used to treat ulcers, bleedings and genitourinary infections in women. They are also known as "barbatimão" and are found both in forest and in canga vegetation. Copaifera martii and Periandra mediterranea are used for rheumatic pains; Sauvagesia cf. erecta and Chamaecrista 
flexuosa are used as anti-inflammatories (Le Cointe 1947, Corrêa 1984, Revilla 2002).

Traditional populations' knowledge about medicinal plants is large and diverse. Posey (2002) reported the use of 53 species by the Kayapó just to treat gastrointestinal diseases. This rich knowledge of traditional populations about these medicinal resources is a heritage orally passed down through the generations up to the present.

Palynological analysis done on human coprolites in Furna do Estrago's archaeological site, in Pernambuco, indicated an ancient interaction between humans and shrub vegetation similar to that found in that region today (Teixeira-Santos et al. 2015). The authors understood that the presence of pollen from Stryphnodendron, Croton, Manihot and Pseudobombax might be related to their analgesics and antiparasitic properties. The ancient use of these taxa, commonly found in the vegetation in Carajás and Pernambuco, stands out. Information regarding the ancient use of medicinal plants in Amazonia may be considered at best preliminary, and mostly comprise of species used as food (Roosevelt et al. 1996, Piperno and Pearsall 1998, Cascon 2010, Caromano et al. 2013).

Material - The high richness of species in this category (Table SI) is related to their several forms of technological use as fibers, dyes, in building, and in making tools and artifacts. Among the fiber providers are Doliocarpus spraguei, Heteropsis flexuosa and Philodendron fragrantissimum, which were inventoried in forest vegetation (the first one is also found in palm swamps) and are related to the production of baskets and ropes (Oliveira et al. 1991, Balée 1994). It is important to note the ancient use of cords and species from genus Philodendron have been shown to have been in use for such purposes in ancient times, as shown by Peixe et al. (2007) by analyzing plant remains found in sambaquis sites, on the Brazilian coast. Trichilia micranta and Myrcia atramentifera are good examples of species used for the production of dyes, and both are found only in forest vegetation. This last one is also known as cumatê and is widely used by Amazonian people to dye bowls. Another important resource is caripé (Licania apetala and L. octandra) whose ashes from the tree bark are mixed with clay for temper in order to provide more resistant pottery (Schultes 1980, 1983). The palm trees Astrocaryum vulgare and Attalea maripa are reportedly used both for making tools and for house-building material (Balée 1994, Revilla 2002). The physical properties of Mezilaurus itauba timber favor its use in the building of houses, canoes and tool handles (Prance 1986).

Game attractant - This category also comprises some species related to human sustenance (Table SI). The fruits of Cordiera myrciifolia, Sacoglottis guianensis, as well as the fruits and flowers of Caryocar villosum attract wildlife. Psychotria hoffmannseggiana was the only exclusive species from this category, and it was found in both forest and canga vegetation. The knowledge of some animal's food preferences regarding plants is strategic, since it supports the selection of the prey and optimizes efforts for its capture. Anderson and Posey (1985) reported some capture strategies by Kayapó, by favoring and maintaining some plant species in backyard and in crop and fallow areas.

Firewood - From 64 species recorded in this category (Table SI), only Eugenia flavescens, from forest vegetation and Machaerium macrophyllum, from palm swamp, were exclusive to it. Among the indigenous Piapoco, from Colombia, there is knowledge about the use of species as fuel and this is passed down through the generations. The local system for obtaining this resource also considers its abundance and distribution in each location. The collection is also influenced by the fuel utility and form of application, which can be firewood, production of charcoal or ashes (Landínez and Linares 2006). 
Archeobotanical studies bring some information about the strategies for obtaining fuel by Brazilian past populations. In sambaquis from the Southeastern-Southern coast, no firewood preference was identified; mostly deadwood was used for this purpose (Scheel-Ybert 2000, 2014). Similar results were obtained for ceramist Tupiguarani populations from Southeastern Brazil. However, when it comes to mortuary rituals, it was demonstrated in Morro Grande site that tree bark was strongly selected (Beauclair et al. 2009, Scheel-Ybert et al. 2014).

Silveira (1994) and Magalhães (2005) identified old fire pits in Serra Norte archaeological sites, where they found seeds of Oenocarpus sp. and Astrocaryum sp., and resins of Hymenaea sp., Vochysia sp. and Copaifera sp., which are considered excellent fuels until today. These findings prove the antiquity of interaction with the local phytophysiognomy by human populations in Carajás, making use of resources from a flora possibly similar to the modern one.

Food - Among the 58 species with alimentary value (Table SI), palm trees such as Mauritia flexuosa, Oenocarpus distichus, Euterpe oleracea and Attalea maripa, and trees such as Caryocar villosum, Sacoglottis guianensis and Anacardium occidentale stand out. According to Balée (1994), these species were classified as of primary use for the Ka'apor, since they have high caloric-energy value and are among the most used in these people's daily diet. Other seldom used species, documented as secondary use are Ambelania acida, Byrsonima densa, Alibertia edulis, species from the genus Inga spp. and Pouteria spp., also inventoried in this study. Other taxa cataloged are important for human feeding: Cereus hexagonus and Ananas ananassoides, which occur exclusively in canga areas, as well as the palm trees Mauritia flexuosa, Mauritiella armata and Euterpe oleracea, which are specific to palm swamps. In this category, Gnetum nodiflorum is one of the few gymnosperms recorded in this region, and which fruit consumption was reported by Cavalcante (1996). The use of Amazon species as food in the archaeological context has already been studied by some authors (Roosevelt et al. 1996, Piperno and Pearsall 1998, Cascon 2010, Caromano et al. 2013), and the plants reported in those studies were also documented in this study, for instance, Attalea sp., Astrocaryum sp. and Sacoglottis sp.

Toxic - fourteen species were represented in this category (Table SI) and were found only in forest vegetation, except Simarouba amara, which, as aforementioned, was found in all three environments. The literature consulted also reported that some plants are considered poisonous only for humans, such as Duroia hirsuta and Stryphnodendron pulcherrimum. Others like Deguelia amazonica, Paullinia pinnata and Serjania paucidentata, known as timbó, are used for fishing (Le Cointe 1947, Balée 1994). The species' Abuta grandifolia and Strychnos amazonica are used in a hunting strategy, since they constitute ingredients of curare, used across the Amazon ( $\mathrm{La}$ Rotta et al. 1987, Schultes and Raffauf 1990).

Ritualistic - among the ten plants found in this category, nine of them were in forest vegetation (Table SI). Mimosa acutistipula, commonly known as jurema, was the only species from this category inventoried in canga vegetation, although, in this study, this species is represented by M. acutistipula var. ferrea. M. acutistipula is used as hallucinogen and as sedative. It is also reported in Ceará's Flora (Braga 1960). The use of species from this genus for ritual is documented in several ceremonies of indigenous people from Northeastern Brazil, through drinking the tea from those plants roots and experiencing hallucinations (Albuquerque 1997, Souza et al. 2008).

As for the forest species, several of them are mentioned in the literature. La Rotta et al. (1987) reported that indigenous groups from the Colombian Amazon use a dye extracted from 
the leaves of Duroia hirsute to paint women and babies bodies in post childbirth, protecting them from diseases caused by spirits. Balée (1994) reported that leaves of Oenocarpus distichus are used in the ceremonies for naming newborns from the Ka'apor; Philodendron acutatum serves as an amulet, which is believed to ensure longer life; Ocotea glomerata is used as a hunting amulet; whereas Licania heteromorfa's resin is used to paint dead people's faces in mortuary rituals and Psychotria colorata is used as an amulet for Ka'apor's boys during the processing of manioc. This latter genus is largely known in the literature about psychoactive plants, for the species $P$. viridis Ruiz \& Pav, when associated to Banisteriopsis caapi (Spruce ex Griseb.) Morton composes the ayahuasca, a hallucinogenic beverage associated with shamanism in Northwestern Amazon. (Schultes 1977, Grenand et al. 1987). Another important species is Virola calophylla, whose use is related to the production of snuff: plant composites prepared for indigenous ceremonies, which can cause hallucinations when inhaled (Schultes and Holmstedt 1968).

It is worth mentioning that although we cited literature involving mainly ethnographic data from Amazonian populations, we recognize that variations may exist in plant use over time. On the other hand, there are species that are consistently used even in widely separated populations in the Amazon, reflecting the heritage of a long process of knowledge transmission and use of the flora. Some uses may be lost over time while others continue to be transmitted between generations (Soldati 2014).

\section{PONTENTIAL USE OF THE PLANT FAMILIES}

The adjusted linear model used ( $y=-$ $0.071303+0.72711 * \mathrm{x})$ explains approximately $90 \%$ of the variation $\left(\mathrm{r}^{2}=0.8988\right)$ of richness of useful species by family. Considering the residual values, Fabaceae, Myrtaceae and Chrysobalanaceae are the families with the highest use potential for species, among the taxa analyzed for Carajás' flora. On the other hand, families such as Bignoniaceae, Apocynaceae, Passifloraceae, Poaceae and Melastomataceae displayed negative residual values, which indicates a pattern of lower potential of use (Table III).

Most species of Myrtaceae and Chrysobalanaceae have their uses documented, which contributes to obtaining positive residual values. The importance of the Myrtaceae recorded are related to dyes, firewood, food and especially medicinal uses, which comprised seven species (Anderson and Posey 1985, Schultes and Raffauf 1990, Grenand and Prévost 1994). The seven useful plants from Chrysobalanaceae, however, comprised all use categories. Five species from the genus Licania stand out, whose application for pottery is well-known in Amazonia (Schultes 1983), which was also confirmed in archaeological ceramics (Costa et al. 2012, Guapindaia and Lopes 2012). Furthermore, this family is one of the most important regarding its utility among some Amazonian ethnic groups (Prance et al. 1987).

Apocynaceae, Bignoniaceae, Passifloraceae, Poaceae and Melastomataceae had less than 50\% of their species with documented uses. These families, with the exception of Apocynaceae and Passifloraceae, displayed a low proportion of useful species in other regions (Moerman 1996), which was also found to be true in this study. Regarding Poaceae, although they comprise worldwide known species like maize (Zea mays L.), rice (Oryza sativa L.) and wheat (Triticum aestivum L.), its low use proportion in other flora has already been verified (Moerman 1996), so this might be a characteristic of this family in larger scales.

The remarkable contribution of Fabaceae in Carajás reflects the large documentation of useful species available, comprising all the use categories covered in this study making it one of the most expressive groups. Fabaceae are among the most 
TABLE III

Residual data of families with higher and lower proportion useful species in Carajás.

\begin{tabular}{ccccc}
\hline High use families & Total richness & useful species richness & Predicted richness & Residual \\
\hline Fabaceae & 31 & 25 & 22.0357 & 2.9643 \\
Myrtaceae & 11 & 10 & 7.7822 & 2.2178 \\
Chrysobalanaceae & 8 & 7 & 5.6441 & 1.3559 \\
\hline Low use families & Total richness & useful species richness & Predicted richness & Residual \\
\hline Bignoniaceae & 8 & 4 & 5.6441 & -1.6441 \\
Apocynaceae & 7 & 3 & 4.9315 & -1.9315 \\
Passifloraceae & 5 & 1 & 3.5061 & -2.5061 \\
Poaceae & 8 & 3 & 5.6441 & -2.6441 \\
Melastomataceae & 15 & 6 & 10.6329 & -4.6329 \\
\hline
\end{tabular}

important families not only in Amazonian flora, but also around the world (Forzza et al. 2014, Moerman 2013). Its importance in North America's flora was widely discussed in other studies, also having variations according to its use as food, medicine and ceremonial plants (Moerman 1996, Turi and Murch 2013). Although Fabaceae has high richness in North America, the number of medicinal species is relatively small (Moerman 1996). In a more recent analysis for this region, there was a high use of this family to make ceremonial items (masks, dyes, rattles, statues and other symbolic items) (Turi and Murch 2013).

The absence of any recorded uses for many species in Carajás caused some families to display no relevance, as with the following: Asteraceae, Combretaceae, Convolvulaceae, Cyperaceae, Dioscoreaceae, Eriocaulaceae, Marantaceae, Orchidaceae, Picramniaceae and Velloziaceae. This result may be related to many factors, such as the fact that most of the species in these families are found only in this kind of environment, mainly in canga vegetation, which are poorly covered in studies of this kind.

\section{RELATION PHYTOPHYSIOGNOMY / ARCHAEOLOGICAL SITES}

Palm swamps - In Serra Sul this phytophysiognomy stands out by differing from hematic canga by having useful species such as Mauritia flexuosa and Euterpe oleracea (Figure 3a). Palynological studies in this area indicated the presence of $M$. flexuosa during the Holocene (Hermanowski et al. 2012) and the use of both species as human food in this period is confirmed by vestiges of phytoliths found on archaeological ceramics in Amazonas state (Cascon 2010, Caromano et al. 2013). Roosevelt et al. (1996), by investigating archaeological sites in Monte Alegre - PA, stated that several palm trees species had already been in use since 11,200 years BP. The species mentioned are among the plant groups with a hyper-dominant distribution in Amazonian flora and which, among other reasons, may be related to human interference (ter Steege et al. 2013). Furthermore, the presence of these plants is usually related to archaeological sites with dark earth soils, so they are among the main indicators of anthropogenic forests (Junqueira et al. 2011, Lins et al. 2015). Other evidence of how important palm trees have always been to human subsistence is the frequency of charred seeds among archaeological remains (Silveira 1994, Roosevelt et al. 1996, Cascon 2010, Caromano et al. 2013, Silva et al. 2013).

In Carajás, this phytophysiognomy is associated with the main archaeological sites analyzed: Capela and Almofariz. According to Magalhães et al. (2016), Capela was considered as 


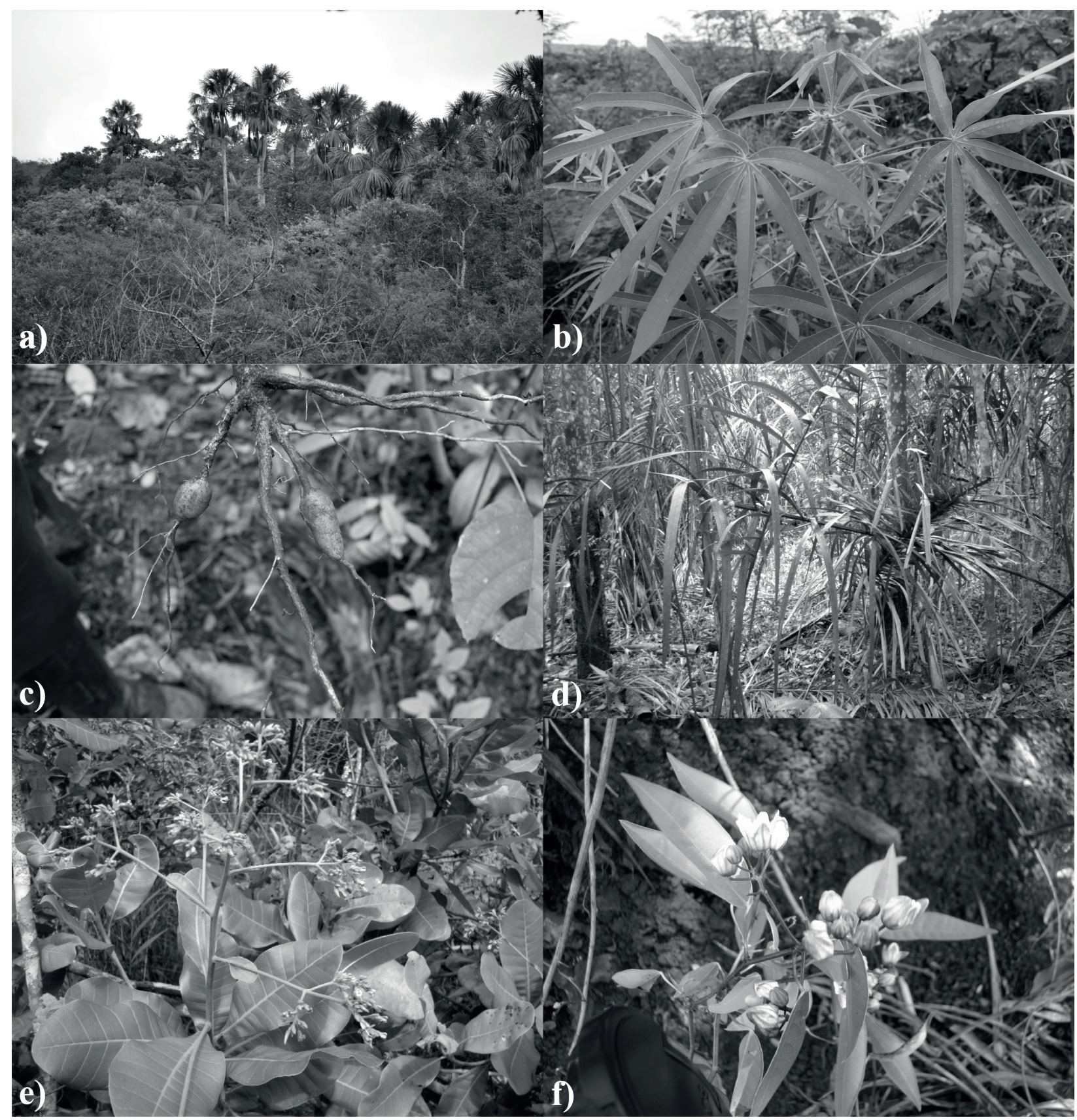

Figure 3 - Useful species recorded in archaeological sites in Serra de Carajás. a) palm swamp; b and c) natural regeneration of Manihot sp.; d) Oenocarpus distichus in capão forests; e) small agglomerations of Anacardium occidentale; f) Manihot sp.

a seasonal dwelling, where artifacts were made and food was processed. Its archaeological material was dated from 11,600 years cal BP, one of the oldest for Amazonia. According to these authors, the second site was probably meant for the production of lithic artifacts related to hunting.
Forest Vegetation - In Serra Sul, a capão forest with important archaeological fragments, plant remains and associated with two rock shelter sites was reported. The canga vegetation around this capão stood out due to the predominance of wild specimens of Manihot sp. (Figure 3b, c), 
besides having a rich floristic composition of edible plants such as Attalea maripa, Caryocar villosum, Oenocarpus distichus and Endopleura uchi (Huber) Cuatrec, among others, explicitly related to anthropogenic factors. Capão forests around the cave called "Gruta do Grilo" have a similar importance, where $O$. distichus prevails (Figure $3 \mathrm{~d}$ ) and in others, where there are associations of $O$. distichus, lianas and A. maripa. The concentration of useful plants found in this capão was higher than in other capão forests studied. The presence of seeds from those species was reported by Silveira (1994) and Magalhães (2005) in their excavations in Serra Norte, where there are sites dated from 9,000 years BP (Magalhães 2005).

Canga vegetation - Anacardium occidentale, Ananas ananassoides and Byrsonima cf. spicata are typical species from this phytophysiognomy. Although some authors (Pires and Prance 1985) consider A. occidentale as typical of savanna, this study shows that it has a rare and dispersed distribution in Carajás, confirming inventories done by Rayol (2006). Small clusters of cashew trees were found (Figure $3 \mathrm{e}$ ) near a cave called "Caverna Gigante" in Serra Sul and near "Gruta do Grilo" in Serra Norte, both associated with individuals of Manihot, which may indicate a past use of this species. It is noteworthy that Roosevelt et al. (1996) have found Anacardium sp. in their excavations in Monte Alegre. It is also important to note the remarkable concentration of Lippia aff. origanoides around the cave, and it is very frequent along the canga. This species may have been an important resource in the past, since it has medicinal properties. Similarly, other taxa such as Norantea sp. and Byrsonima sp., which are abundant in this environment, had their presences verified in archaeological vestiges from other sites in Amazonia (Roosevelt 2000, 2013).

Furthermore, individuals of Manihot sp. were found near Caverna Gigante and seem to be $M$. esculenta (Figure 3f), whose structural changes might be a consequence of environmental conditions in canga. However, the confirmation of this hypothesis depends on molecular analysis by specialists on the material collected. If confirmed, such findings, along with the ones from Silveira (1994) and Magalhães (2005), who found seeds of Manihot sp. in their excavations, would be an important contribution for the investigation on the management of this and other species by past nomadic populations in this region.

The archaeological remains analyzed from the sites in this study are related to different occupation periods (see Table IV) and two distinct historical processes: One referring to generalist nomadic populations (Tropical Culture) and another to sedentary farming populations (Antropical Culture) (Magalhães 2013, 2016), which features polished and chipped instruments of material such as quartz, pebble and hematite, as well as a simple pottery style adorned with Tupi-Guarani decorations, respectively (Magalhães et al. 2016). It should be noted that some of the ceramic artifacts found indicated ritualistic use (Figure 4a) and others indicated food handling (Figure 4b).

Most of the sites had areas with high concentrations of charcoal (Figure 4c), as well as fruit fragments and charred seeds such as Caryocar sp. (Figure 4d) and mostly palm trees (Figure 4e, f), besides other non-identified seeds (field check). The plant remains (macro and micro remains) are one of the most important clues to understanding the use of flora in the past, since they are closely related to the archaeological context and this allows making more accurate comparisons between the resources used in the past and the ones found today (Peixe et al. 2007, Cascon 2010).

\section{CONCLUSIONS}

The high expressivity of useful plants found in all the phytophysiognomies analyzed was a strategic condition for permanent or temporary establishment 


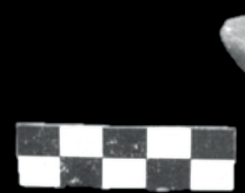

a)

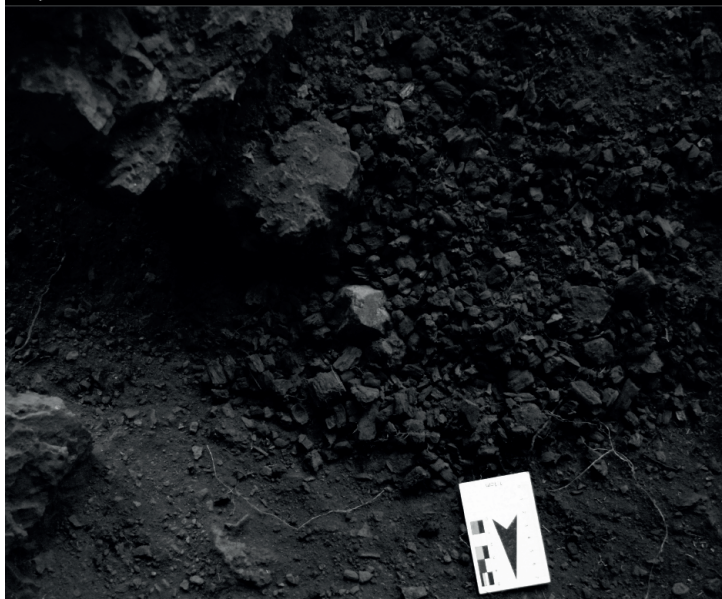

c)

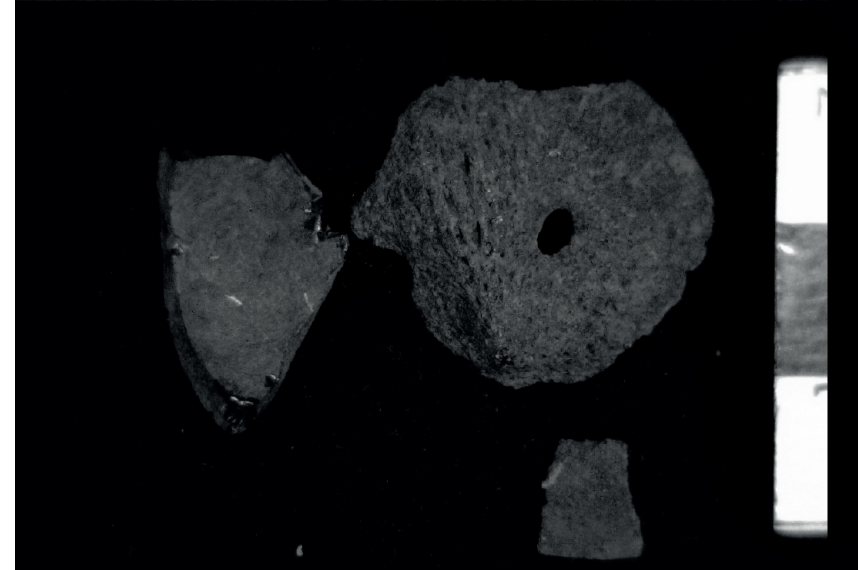

e)

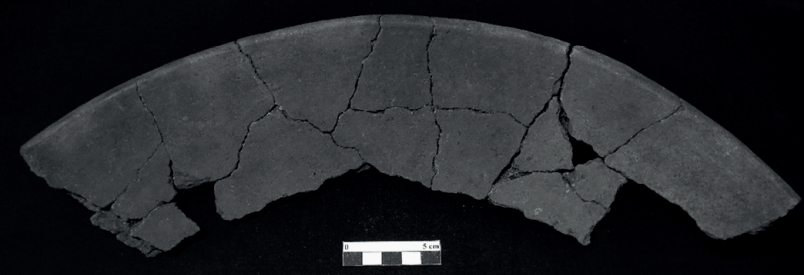

b)

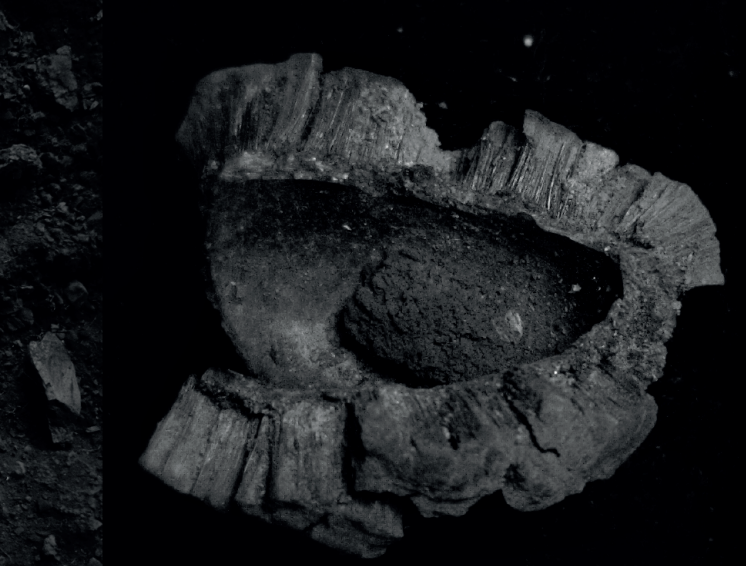

d)

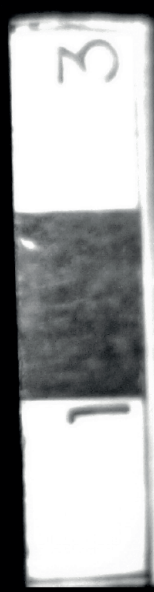

f )

Figure 4 - Archaeological and botanical fragments recorded in sites in Serra de Carajás. a and b) ceramic artifacts; c) fire structure; d) seeds Caryocar sp.; e and f) seeds of Arecaceae. Source: Projeto arqueológico Carajás - PACA. 
TABLE IV

Dating site from Serras Norte and Sul de Carajás, calibrated in from program OxCal 4.2 (Bronk Ramsey 2009), adopting a probability level of $95 \%$ ( 2 sigmas).

\begin{tabular}{|c|c|c|c|c|c|c|c|c|}
\hline Reference & Site & Mountain & $\begin{array}{c}\text { Laboratory } \\
\text { /code }\end{array}$ & $\begin{array}{c}\text { Dated } \\
\text { material }\end{array}$ & $\begin{array}{c}\text { Level } \\
\text { (depth) }\end{array}$ & $\begin{array}{l}\text { Dating } \\
\text { method }\end{array}$ & $\begin{array}{c}\text { Dating } \\
\text { (yars BP) }\end{array}$ & $\begin{array}{c}\text { Calibrated } \\
\text { date } \\
\text { (cal BP) }\end{array}$ \\
\hline $\begin{array}{l}\text { Magalhães } \\
\text { et al. (2016) }\end{array}$ & $\begin{array}{l}\text { PA-AT-337: } \\
\text { S11D 47/48 } \\
\quad \text { (Gruta) }\end{array}$ & South & $\begin{array}{c}\text { Beta } \\
410465\end{array}$ & Charcoal & $17(80-85 \mathrm{~cm})$ & AMS & $10010 \pm 40$ & $11750-11236$ \\
\hline $\begin{array}{l}\text { Magalhães } \\
\text { (2005) }\end{array}$ & $\begin{array}{l}\text { Gruta do } \\
\text { Pequiá }\end{array}$ & North & $\begin{array}{c}\text { Beta } \\
110699\end{array}$ & Charcoal & 50 & - & $9000 \pm 50$ & $10247-9776$ \\
\hline $\begin{array}{l}\text { Silveira } \\
\text { (1994) }\end{array}$ & $\begin{array}{l}\text { Gruta do } \\
\text { Gavião }\end{array}$ & North & GX 12511 & Charcoal & $(30-40 \mathrm{~cm})$ & - & $7925 \pm 45$ & $8996-8540$ \\
\hline $\begin{array}{l}\text { Magalhães } \\
\text { et al. (2016) }\end{array}$ & $\begin{array}{l}\text { PA-AT-337: } \\
\text { S11D 47/48 } \\
\quad \text { (Gruta) }\end{array}$ & South & $\begin{array}{c}\text { Beta } \\
410470\end{array}$ & Charcoal & $10(45-50 \mathrm{~cm})$ & AMS & $4610 \pm 30$ & $5461-5040$ \\
\hline $\begin{array}{l}\text { Magalhães } \\
\text { et al. (2016) }\end{array}$ & $\begin{array}{l}\text { PA-AT-337: } \\
\text { S11D 47/48 } \\
\quad \text { (Gruta) }\end{array}$ & South & $\begin{array}{c}\text { Beta } \\
380860\end{array}$ & Charcoal & $3(5-10 \mathrm{~cm})$ & AMS & $2600 \pm 30$ & $2775-2457$ \\
\hline $\begin{array}{l}\text { Magalhães } \\
\text { et al. (2016) }\end{array}$ & $\begin{array}{l}\text { PA-AT-337: } \\
\text { S11D 47/48 } \\
\quad \text { (Gruta) }\end{array}$ & South & $\begin{array}{c}\text { Beta } \\
380854\end{array}$ & Charcoal & $5(20-25 \mathrm{~cm})$ & AMS & $1250 \pm 30$ & $1270-981$ \\
\hline $\begin{array}{l}\text { Magalhães } \\
\text { et al. (2016) }\end{array}$ & $\begin{array}{l}\text { PA-AT-337: } \\
\text { S11D 47/48 } \\
\text { (Abrigo) }\end{array}$ & South & $\begin{array}{c}\text { Beta } \\
380865\end{array}$ & Charcoal & $2(10-20 \mathrm{~cm})$ & AMS & $220 \pm 30$ & 313 - Post BP 0 \\
\hline
\end{tabular}

of past populations in Serra de Carajás. Many of these species reported are testimonies of flora recorded since the Holocene (Absy et al. 1991, Silveira 1994, Magalhães 2005, Hermanowski et al. 2012). Nevertheless, it is suggested that after some period of occupation, humans appropriated local resources and modified them according to their subsistence needs (Alcorn 1981, Anderson and Posey 1985). Thus, there is strong evidence that past populations developed activities that shaped the environment according to their needs (Heckenberger et al. 2003, Levis et al. 2012, Balée et al. 2014, Scheel-Ybert et al. 2016). The present study demonstrates that, on the plateaus, these changes in vegetation can be noticed through the concentration of useful plants around archaeological sites.

\section{ACKNOWLEDGMENTS}

The authors would like to thank the technicians from MG herbarium and from the Laboratório de Arqueologia do Museu Paraense Emílio Goeldi, to the specialists for the support in species identification, especially to Dr. Pedro Lage Viana; to the Post Graduation Program in Biodiversity and Biotechnology from Rede Bionorte (PPGBIONORTE) and to the Projeto Arqueológico Carajás (PACA), in which the research was carried out. The present study is part of the doctoral thesis of the first author.

\section{AUTHOR CONTRIBUTIONS}

The manuscript was elaborated from interdisciplinary researches developed by Ronize Santos, Márlia Coelho-Ferreira, Pedro Glécio Costa Lima and Marcos Pereira Magalhães. The theoretical-methodological approach to ethnobotany and archeology, as well as the questions guiding the research were conceived and discussed by all authors. The archaeological contextualization, selection and evaluation of the sites were carried out mainly by Marcos Magalhães and Ronize Santos. The methodological design, 
collection and analysis of the ethnobotanical data related to the use and cultural aspects of the inventoried species resulted from the collaboration between Ronize Santos, Márlia Coelho-Ferreira and Pedro Glécio. All the autors participated of the construction and critical review of the discussion and final text.

\section{REFERENCES}

ABSY ML ET AL. 1991. Mise en évidence de quatre phases d'ouverture de la forêt dense dans le sud-est de L'Amazonie au cours des 60,000 dernières années. Première comparaison avec d'autres régions tropicales. Compt Rend Acad des Sci Paris, Series II 312: 673-678.

ALBUQUERQUE UP. 1997. Folhas sagradas: as plantas litúrgicas e medicinais nos cultos afro-brasileiros, Recife: Universitária da UFPE, 197 p.

ALCORN JB. 1981. Huastec noncrop resources management: implications for prehistoric rain forest management. Hum Ecol 9: 395-417.

AMOROZO MCM. 1993. Algumas notas adicionais sobre o emprego de plantas e outros produtos com fins terapêuticos pela população cabocla do município de Barcarena, PA, Brasil. Bol Mus Para Emílio Goeldi Bot 9: 249-266.

AMOROZO MCM AND GÉLY AL. 1988. Uso de plantas medicinais por caboclos do baixo Amazonas, Barcarena, PA, Brasil. Bol Mus Para Emílio Goeldi Bot 4: 47-131.

ANDERSON AB AND POSEY DA. 1985. Manejo de cerrado pelos índios Kayapó. Bol Mus Para Emílio Goeldi Bot 2: 77-98.

ANDERSON AB AND POSEY DA. 1989. Management of a tropical scrub savanna by the Gorotire Kayapó of Brazil. In: Posey DA and Balée W (Eds), Resource management in Amazonia: indigenous and folk strategies, Adv Econ Bot: New York Botanical Garden, New York, USA, p. 159173.

APG III - THE ANGIOSPERM PHYLOGENY GROUP. 2009. An update of the Angiosperm Phylogeny Group classification for the orders and families of flowering plants. Bot J Linn Soc 161: 105-121.

BALÉE W. 1986. Analise preliminar de inventário florestal e a etnobotânica Ka'apor (Maranhão). Bol Mus Para Emílio Goeldi Bot 2: 141-167.

BALÉE W. 1987. A etnobotânica quantitativa dos índios Tembé (Rio Gurupi, Pará). Bol Mus Para Emílio Goeldi Bot 3: 29-47.

BALÉE W. 1989. The culture of Amazonian forests. In: Posey DA and Balée W (Eds), Resource management in Amazonia: indigenous and folk strategies, Adv Econ Bot: New York Botanical Garden, New York, USA, p. 1-21.
BALÉE W. 1994. Footprints of the forest: Ka'apor ethobotany - the historical ecology of plan utilization by an Amazonian people, New York: Columbia University Press, 419 p.

BALÉE W, SCHAAN DP, WHITAKER JA AND HOLANDA R. 2014. Florestas antrópicas no Acre: inventário florestal no geoglifo Três Vertentes, Acrelândia. Amaz Rev Antropol 6: 140-169.

BEAUCLAIR M, SCHEEL-YBERT R, BIANCHINI GF AND BUARQUE A. 2009. Fire and ritual: bark hearths in South-American Tupiguarani mortuary rites. J Archaeol Sci 36: 1409-1415.

BERG MEVD. 2010. Plantas medicinais na Amazônia, $3^{\text {a }}$ ed., Belém: Museu Paraense Emilio Goeldi, 268 p.

BRAGA R. 1960. Plantas do Nordeste: especialmente do Ceará, $2^{\mathrm{a}}$ ed., Fortaleza: Editora Imprensa Oficial, 540 p.

BRASIL. 1974. Projeto Radam - Tocantins: Vegetação. Companhia Vale do Rio Doce - 1980. Relatório de reavaliação da jazida de ferro N4 do Distrito Ferrífero da Serra dos Carajás, DNPM, Rio de Janeiro, Folha S. C. 22, p. 26-29.

BUENO L AND PEREIRA E. 2015. Indústrias líticas em sítios cerâmicos na Amazônia: um estudo do sítio Domingos, Canaã dos Carajás, Pará. Rev Mus Arqueol Etnologia 17: 99-126.

CAROMANO CF, CASCON LM, NEVES EG AND SCHEEL-YBERT R. 2013. Revealing fires and rich diets: macro-and micro-archaeobotanical analysis at the Hatahara Site, Central Amazonia. Tipití: J Soc Anthropol Lowl S Am 11: 40-51.

CASCON LM. 2010. Alimentação na floresta tropical: Um estudo de caso no sítio Hatahara, Amazônia Central, com base em microvestígios botânicos, 195 p. Dissertação de Mestrado. Universidade Federal do Rio de Janeiro/ Museu Nacional, Rio de Janeiro. (Unpublished).

CAVALCANTE PB. 1996. Frutas comestíveis na Amazônia, $6^{\mathrm{a}}$ ed., Belém: CNPq/Museu Paraense Emilio Goeldi, 279 p.

CAVALCANTE PB. 2010. Frutas comestíveis na Amazônia, $7^{\mathrm{a}}$ ed., Belém: Museu Paraense Emilio Goeldi, 280 p.

CAVALCANTE PB AND FRIKEL P. 1973. A Farmacopéia Tiriyó: estudo étno-botânico, n. 24, Belém: Museu Paraense Emílio Goeldi, 143 p.

COELHO-FERREIRA MR. 2008. Notas etnobotânicas sobre as plantas medicinais. In: Jardim MAG and Zoghbi MGB (Eds), A flora da Resex Chocoaré-Mato Grosso (PA): Diversidade e usos, coleção Adolpho Ducke, Museu Paraense Emílio Goeldi, Belém, p. 63-90.

COELHO-FERREIRA MR. 2009. Medicinal knowledge and plant utilization in an Amazonian coastal community of Marudá, Pará State (Brazil). J Ethnopharmacol 126: 159175.

COELHO-FERREIRA MR AND SILVA MFF. 2005. A Fitofarmacopéia da comunidade Pesqueira de Marudá, 
Litoral Paraense. Bol Mus Para Emilio Goeldi Cienc Nat 1: $31-43$

COOK FEM. 1995. Economic botany data collection standard, Royal Botanic Gardens (Kew): United Kingdom, 146 p.

CORRÊA MP. 1984. Dicionário das plantas úteis do Brasil e das exóticas cultivadas, $6^{\mathrm{a}}$ ed., Rio de Janeiro: Imprensa Nacional, 747 p.

COSTA BLS, PY-DANIEL AR, GOMES J AND NEVES EG. 2012. Urnas Funerárias no Lago Amanã, Médio Solimões, Amazonas: Contextos, gestos e processos de conservação. Amaz Rev Antropol 4: 60-91.

DUKE JA. 1970. Ethnobotanical observations on the Chocó indians. Econ Bot 24: 344-366.

EGG AB. 1993. Plantas nativas utilizadas en el Peru en relacion con la salud humana. In: Estrella E and Crespo A (Eds), Memorias del I Simposio Salud y Poblacion Indigena de la Amazonia, Tratado de Cooperacion Amazonica, Quito, p. 61-175.

ERICKSON CL AND BALÉE W. 2006. The Historical Ecology of a Complex Landscape in Bolivia. In: Balée W and Erickson CL (Eds), Time and Complexity in Historical Ecology: Studies in the Neotropical Lowlands, Columbia University Press, New York, p. 187-233.

FALCI CG AND RODET MJ. 2016. Adornos corporais em Carajás: a produção de contas líticas em uma perspectiva regional. Bol Mus Para Emílio Goeldi Ciênc Hum 11: 481503.

FORZZA RC ET AL. 2014. Lista de Espécies da Flora do Brasil. Disponível em: http://floradobrasil.jbrj.gov.br/. (Acesso em 30 de Junho, 2015).

GRENAND P, MORETTI C, JACQUEMIN H AND PRÉVOST MF. 1987. Pharmacopées traditionnelles en Guyane: créoles, palikur, wayãpi, n. 108, Paris: Orstom, $569 \mathrm{p}$.

GRENAND P AND PRÉVOST MF. 1994. Les plantes colorantes utilisées en Guyane française. J Agric Trad Bot Appl 36: 139-172.

GUAPINDAIA V AND LOPES D. 2012. Estudos arqueológicos na região de Porto Trombetas, PA. Rev Arqueol 24: 50-73.

HECKENBERGER MJ, KUIKURO A, KUIKURO UT, RUSSELL JC, SCHMIDT M, FAUSTO C AND FRANCHETTO B. 2003. Amazonia 1492: pristine forest or cultural parkland? Science 301: 1710-1713.

HERMANOWSKI B, COSTA ML AND BEHLING H. 2012. Environmental changes in southeastern Amazonia during the last 25,000 year revealed from a paleoecological record. Quaternary Res 77: 138-148.

HOEHNE FC. 1978. Plantas e substâncias vegetais tóxicas e medicinais, São Paulo: Novos Horizontes, 355 p.

IBAMA - INSTITUTO BRASILEIRO DO MEIO AMBIENTE E DOS RECURSOS NATURAIS RENOVÁVEIS. 2003.
Plano de manejo para uso múltiplo da Floresta Nacional de Carajás, 736 p.

JUNQUEIRA AB, SHEPARD GH AND CLEMENT C. 2011. Secondary forests on anthropogenic soils of the Middle Madeira river: valuation, local knowledge, and landscape domestication in Brazilian Amazonia. Econ Bot 65: 85-99.

KIPNIS R, CALDARELLI SB AND OLIVEIRA WC. 2005. Contribuição para a cronologia da colonização amazônica e suas implicações teóricas. Rev Arqueol 18: 81-93.

LA ROTTA C, MIRAÑA P, MIRAÑA M, MIRAÑA B, MIRAÑAMAND YUCUNAN. 1987. Estudio etnobotanico sobre las espécies utilizadas por la comunidad indígena Miraña, Amazonas, Colombia: FEN, WWF, 309 p.

LANDÍNEZ A AND LINARES E. 2006. Plantas dendroenergéticas utilizadas por una comunidade indígena Piapoco em Guainía, Colombia. Cult Científica 4: 29-34.

LE COINTE P. 1931. Apontamento sobre as sementes oleaginosas, bálsamos, resinas, essências, borrachas, guttas e balatas da floresta amazônica, Rio de Janeiro: Departamento Nacional de Estatística, 60 p.

LE COINTE P. 1945. O Estado do Pará: A terra, a água e o ar, São Paulo: Companhia Editora Nacional, 305 p.

LE COINTE P. 1947. Amazônia brasileira. III. Árvores e plantas úteis (indígenas e aclimatadas), São Paulo: Companhia Editora Nacional, 506 p.

LEONI J AND MARQUES T. 2008. Conhecimento de artesãos sobre as plantas utilizadas na produção de artefatos Reserva de Desenvolvimento Sustentável Amanã - AM. Uakari 4: 67-77.

LEVIS C, DE SOUZA PF, SCHIETTI J, EMILIO T, DA VEIGA PINTO JLP, CLEMENT CR AND COSTA FR. 2012. Historical human footprint on modern tree species composition in the Purus-Madeira interfluve, Central Amazonia. PLoS ONE 7: 1-10.

LINS J, LIMA HP, BACCARO FB, KINUPP VF, SHEPARD GH AND CLEMENT CR. 2015. Pre-Columbian Floristic Legacies in Modern Homegardens of Central Amazonia. PLoS ONE 10: 1-10.

LISBOA PLB. 2012. A terra dos Aruã: Uma história ecológica do arquipélago do Marajó, Belém: Museu Paraense Emilio Goeldi, $481 \mathrm{p}$.

LISTA DE ESPÉCIE DA FLORA DO BRASIL. 2015. Jardim Botânico do Rio de Janeiro. Eletronic resource. Disponível em: <http://floradobrasil.jbrj.gov.br/>. (Acesso em Dezembro, 2015).

MAGALHÃES MP. 2005. A Phýsis da Origem: o sentido da história na Amazônia, Belém: Museu Paraense Emílio Goeldi, $351 \mathrm{p}$.

MAGALHÃES MP. 2013. Território cultural e a transformação da floresta em artefato social. Bol Mus Para Emílio Goeldi Ciênc Hum 8: 381-400.

MAGALHÃES MP. 2016. A Cultura Tropical e a gênese da Amazônia antropogênica. In: Magalhães MP (Ed), 
Amazônia Antropogênica. Museu Paraense Emílio Goeldi, Belém, p. 241-258.

MAGALHÃES MP, BARBOSA CAP, FONSECA JA, SCHMIDT MJ, MAIA RR, MENDES K, MATOS A AND MAURITY G. 2016. Carajás. In: Magalhães MP (Ed), Amazônia antropogênica, Museu Paraense Emílio Goeldi, Belém, p. 259-308.

MILLER RP, WANDELLI EV AND GRENAND P. 1989. Conhecimento e utilização da floresta pelos índios Waimiri-Atroari do Rio Camanau-Amazonas. Acta Bot Bras 3: 47-56.

MISSOURI BOTANICAL GARDEN. 2015. Tropicos.org. Eletronic resource. Available at: $<$ http://www.tropicos. org $>$. (Accessed in December, 2015).

MOERMAN DE. 1996. An analysis of the food plants and drug plants of native North America. J Ethnopharmacol 52: $1-22$.

MOERMAN DE. 2013. The Global Flora: Descriptive statistics with a commentary and an ethnobotanical example. Ethnobot Res Appl 11: 109-119.

MORELLATO LPC AND ROSA NA. 1991. Caracterização de alguns tipos de vegetação na região amazônica, Serra dos Carajás, Pará, Brasil. Rev Bras Bot 14: 1-14.

NUNES JA. 2009. Florística, estrutura e relações solovegetação em gradiente fitofisionômico sobre canga, na serra sul, Flona de Carajás-Pará, 101 p. Dissertação de Mestrado. Universidade Federal de Viçosa, Minas Gerais. (Unpublished).

NUNES JA, SCHAEFER CEGR, FERREIRA JÚNIOR WG, NERI AV, CORREA GR AND ENRIGHT NJ. 2015. Soilvegetation relationships on a banded ironstone 'island', Carajás Plateau, Brazilian Eastern Amazonia. An Acad Bras Cienc 87: 2097-2110.

OLIVEIRA J, ALMEIDA SS, VILHENA POTYGUARA RC AND LOBATO LCB. 1991. Espécies vegetais produtoras de fibras utilizadas por comunidades amazônicas. Bol Mus Para Emílio Goeldi Bot 7: 393-428.

OLIVEIRA J, VILHENA POTYGUARA RC AND LOBATO LCB. 2006. Fibras vegetais utilizadas na pesca artesanal na microrregião Salgado, Pará. Bol Mus Para Emílio Goeldi Bot 1: 113-127.

PARADELLA WR, SILVA MFF AND ROSA NDA. 1994. A geobotanical approach to the tropical rain forest environment of the Carajás Mineral Province (Amazon Region, Brazil), based on digital TM-Landsat and DEM data. Int J Remote Sens 15: 1633-1648.

PEIXE SP, MELO JR JCF AND BANDEIRA DR. 2007. Paleoetnobotânica dos macrorestos vegetais do tipo trançado de fibras encontrados no Sambaqui Cubatão I, Joinville-SC. Rev Mus Arqueol Etnologia 17: 211-222.

PEIXOTO AM, TOLEDO FF, REICHARDT K AND SOUSA JSI. 1998. Enciclopédia Agrícola Brasileira. São Paulo: Universidade de São Paulo, Edusp.
PIPERNO DR AND PEARSALL DM. 1998. The origins of agriculture in the lowland Neotropics, $400 \mathrm{p}$.

PIRES JM AND PRANCE GT. 1985. The vegetation types of the Brazilian Amazon. In: Prance GT and Lovejoy TE (Eds), Key environments Amazônia, Pergamon Press, New York, p. 109-145.

POSEY DA. 2002. Kayapó ethnoecology and culture. In: Roy Ellen (Ed), Studies environmental anthropology, University of Kent at Canterbury UK, London and New York, p. 1-304.

PRANCE GT. 1986. Manual de botânica econômica do Maranhão, São Luís: Universidade Federal do Maranhão, $254 \mathrm{p}$.

PRANCE GT, BALEÉ W, BOOM BM AND CARNEIRO RL. 1987. Quantitative ethnobotany and the case for conservation in Ammonia. Conserv Biol 1: 296-310.

RAYOL BP. 2006. Análise florística e estrutural da vegetação xerofítica das savanas metalófilas na Floresta Nacional de Carajás: subsídios à conservação, 87 p. Dissertação de Mestrado. Universidade Federal Rural da Amazônia/ Museu Paraense Emílio Goeldi, Belém. (Unpublished).

REVILLA R. 2002. Plantas úteis da Bacia Amazônica, Manaus: SEBRAE-AM/INPA, 858 p.

RODRIGUES E. 2006. Plants and animals utilized as medicines in the Jaú National Park (JNP), Brazilian Amazon. Phytother Res 20: 378-391.

ROOSEVELT AC. 2000. The lower Amazon: a dynamic human habitat. In: Lentz D (Ed), Imperfect balance: Landscape transformations in the Precolumbian Americas. Columbia University, NY, p. 455-491.

ROOSEVELT AC. 2013. The Amazon and the anthropocene: 13,000 years of human influence in a tropical rainforest. Anthropocene 4: 69-87.

ROOSEVELT AC ET AL. 1996. Paleo-Indian cave dwellers in the Amazon: the Peopling of the Americas. Science 272: 373-384.

SCHAEFER CEGR, MENDONÇA BAF, JÚNIOR WGF AND CORRÊA GR. 2012. Relação solo-vegetação em alguns ambientes brasileiros: Fatores edáficos e florística. In: Martins SV (Ed), Ecologia de florestas tropicais do Brasil, Universidade Federal de Viçosa, p. 252-293.

SCHEEL-YBERT R. 2000. Vegetation stability in the southeastern Brazilian coastal area from 5500 to 1400 14C yr BP deduced from charcoal analysis. Rev of Palaeobot Palynol 110: 111-138.

SCHEEL-YBERT R. 2014. Landscape and use of plants by Southern and Southeastern Brazilian Shell Mound Builders. In: Roksandic M, Souza SM, Eggers S, Burchell $\mathrm{M}$ and Klokler D (Eds), The cultural dynamics of ShellMatrix sites. University of New Mexico Press, p. 289-300. SCHEEL-YBERT R, BEAUCLAIR M AND BUARQUE A. 2014. The forest people: landscape and firewood use in 
the Araruama region, southeastern Brazil, during the late Holocene. Vegetat Hist Archaeobot 22: 1-17.

SCHEEL-YBERT R, CAROMANO CF AND AZEVEDO LW. 2016. Of forests and gardens: landscape, environment, and cultural choices in Amazonia, Southeastern and Southern Brazil from c. 3000 to 300 cal yrs BP. Cadernos do Lepaarq 13: 425-458.

SCHULTES RE. 1977. Avenues for future ethnobotanical research into new world hallucinogens and their uses. In: Du Toit BM (Ed), Drugs, rituals and altered states of consciousness, University of Florida, p. 261-267.

SCHULTES RE. 1979. De plantis toxicariis e mundo novo tropicale commentationes XIX. Biodynamic Apocynaceous plants of the northwest Amazon. J Ethnopharmacol 1: 165192.

SCHULTES RE. 1980. De plantis toxicariis e mundo novo tropicale commentationes XXVI. Ethnopharmacological notes on the flora of Northwestern South America. Bot Mus Leafl Harv Univ 28: 1-45.

SCHULTES RE. 1983. De plantis toxicariis e mundo novo tropicale commentationes XXXII. Notes, primarily of field tests and native nomenclature, on biodynamic plants of the Northwest Amazon. Bot Mus Leafl Harv Univ 29: 251272.

SCHULTES RE AND HOLMSTEDT B. 1968. De plantis toxicariis e mundo novo tropicale commentationes II. The vegetal ingredientes of the myristicaceous snuffs of the Northwest Amazon. Rhodora 70: 113-160.

SCHULTES RE AND RAFFAUF RF. 1990. The Healing Forest: Medicinal and Toxic Plants of the Northwest Amazonia. Dioscorides Press, Portland, Oregon, 484 p.

SECCO RS AND MESQUITA AL. 1983. Notas sobre a vegetação de Canga da Serra Norte - I. Bol Mus Para Emílio Goeldi Bot 59: 1-13.

SHANLEY P AND ROSA NA. 2005. Um inventário etnobotânico na fronteira de exploração da Amazônia Oriental. Bol Mus Para Emilio Goeldi Cienc Nat 1: 147171.

SILVAFM, SHOCK M, NEVES EG, LIMAHPAND SCHEELYBERT R. 2013. Recuperação de macrovestígios em sítios arqueológicos na Amazônia: nova proposta metodológica para estudos arqueobotânicos. Bol Mus Para Emílio Goeldi Ciênc Hum 8: 759-769.

SILVA MF, LISBOA PLB AND LISBOA RCL. 1977. Nomes vulgares de plantas amazônicas, Manaus: Falangola, 222 p.
SILVA MFF, SECCO R AND LOBO MGA. 1996. Aspectos ecológicos da vegetação rupestre da Serra dos Carajás, Estado do Pará, Brasil. Acta Amaz 26: 17-44.

SILVEIRA MI. 1994. Estudos sobre estratégias de subsistência de caçadores-coletores pré-históricos do sítio Gruta do Gavião, Carajás/PA, 151 p. Dissertação de Mestrado. Universidade de São Paulo, São Paulo. (Unpublished).

SOLDATI GT. 2014. A transmissão do conhecimento local ou tradicional e o uso dos recursos naturais. In: Albuquerque UP (Ed), Introdução à etnobiologia, NUPEEA, Recife, p. 151-156.

SOUZA RSO, ALBUQUERQUE UP, MONTEIRO JM AND AMORIM ELC. 2008. Jurema-Preta (Mimosa tenuiflora [Willd.] Poir.): a review of its traditional use, phytochemistry and pharmacology. Braz Arch Biol Techn 51: 937-947.

TEIXEIRA-SANTOS L, SIANTO A, ARAÚJO KJ AND REINHARD SAM. 2015. The evidence of medicinal plants in human sediments from Furna do Estrago prehistoric site, Pernambuco State, Brazil. Quatern Int 377: 112-117.

TER STEEGE H ET AL. 2013. Hyperdominance in the Amazonian tree flora. Science 342: 1243092.

THE PLANT LIST. 2015. Published on the Internet. Eletronic resource. Available at: <http://www.theplantlist.org/>. (Accessed in December, 2015).

TURI CE AND MURCH SJ. 2013. Spiritual and ceremonial plants in North America: An assessment of Moerman's ethnobotanical database comparing residual, binomial, bayesian and imprecise dirichlet model (IDM) analysis. J Ethnopharmacol 148: 386-394.

VÁSQUEZ SPF, MENDONÇA MS AND NODA SN. 2014. Etnobotânica de plantas medicinais em comunidades ribeirinhas do Município de Manacapuru, Amazonas, Brasil. Acta Amaz 44: 457-472.

VILHENA-POTIGUARA RC, ALMEIDA SS, OLIVEIRA J, LOBATO LC B AND LINS ALFA. 1987. Plantas Fibrosas - I. Levantamento botânico na microrregião do Salgado (Pará, Brasil). Bol Mus Para Emílio Goeldi Bot 3: 279301.

\section{SUPPLEMENTARY MATERIAL}

Table SI - Useful plants inventoried in archaeological sites in Serra de Carajás, Pará, Brazil. 